\title{
VDR Activation Reduces Proteinuria and High-Glucose-Induced Injury of Kidneys and Podocytes by Regulating Wnt Signaling Pathway
}

\author{
Jia Guo a,b,c Congqun Lu ${ }^{a, b, c}$ Fangxing Zhang ${ }^{a, b, c}$ Haixia Yu $u^{a, b, c}$ Mengwen Zhou ${ }^{a, b, c}$ \\ Meixia He $^{d}$ Chunyan Wanga,b,c Zhanzheng Zhao a,b,c Zhangsuo Liu ${ }^{a, b, c}$
}

aNephrology Center of First Affiliated Hospital of Zhengzhou University, Zhengzhou, bZhengzhou University Institute of Nephrology, Zhengzhou, 'Institute of Clinical Medicine, The First Affiliated Hospital of Zhengzhou University, Zhengzhou, dHenan Academy of Medical and Pharmaceutical Sciences, Zhengzhou University, Zhengzhou, China

\section{Key Words}

Diabetic nephropathy $\cdot$ Proteinuria $\cdot$ Podocytes $\cdot$ Vitamin D receptor $\cdot$ Paricalcitol $\cdot$ Wnt signaling pathway

\begin{abstract}
Background: Diabetic nephropathy (DN) is a major cause of end-stage renal disease and proteinuria is one of the most prominent clinical manifestations. The expression of Vitamin $D$ receptor (VDR) in patients with chronic kidney diseases was decreased, while VDR agonists could partially alleviate the proteinuria of DN in animal models. The present study was designed to determine the expression of VDR in renal tissues and its relationship with proteinuria the diabetic model $\mathrm{db} / \mathrm{db}$ mice. Methods: The regulation effects of VDR on the Wnt signaling pathway were analyzed using RNA interference and VDR agonist paricalcitol. Results: With the increase in age of the $\mathrm{db} / \mathrm{db}$ mice, the VDR protein and mRNA levels in renal tissues were decreased, proteinuria increased, and the protein and mRNA levels of GSK-3 $\beta$ of and $\beta$-catenin increased. Paricalcitol treatment resulted in the up-regulation of VDR and down-regulation of GSK-3 $\beta$ and $\beta$-catenin, indicating that VDR had a regulatory effect on the Wnt signaling pathway. Conclusion: VDR activation could reduce proteinuria of DN mice and alleviate highglucose-induced injury of kidneys and podocytes by regulating the key molecules of Wnt signaling pathway.
\end{abstract}

(C) 2017 The Author(s)

Published by S. Karger AG, Basel

\section{Introduction}

Diabetes poses a major public health problem worldwide, with ever-increasing incidence and prevalence in recent years. Diabetic nephropathy (DN) is one of the most 


\section{Cellular Physiology Cell Physiol Biochem 2017;43:39-51 \begin{tabular}{l|l|l} 
and Biochemistry & Dubl1159/000480315 24,2017 & $\begin{array}{l}\text { C) } 2017 \text { The Author(s). Published by S. Karger AG, Basel } \\
\text { www.karger.com/cpb }\end{array}$
\end{tabular} \\ Guo et al.: Proteinuria and High-Glucose-Induced Injury of Kidneys and Podocytes}

common microvascular complications of patients with diabetes, which is characterized by structural and functional changes in the kidneys, leading to end-stage renal disease (ESRD). The major clinical manifestations of DN are proteinuria, hematuria, and progressive chronic kidney disease $[1,2]$. Proteinuria is one of the most common clinical manifestations of DN and closely correlates with mesenchymal cell trans-differentiation and barrier functional injury. Podocytes are highly differentiated epithelial cells located in the glomerular basement membrane, forming the outermost layers of the glomerular filtration. There is a relationship between podocyte injury and the occurrence and progression of albuminuria. Proteinuria can cause DN deterioration, developing into ESRD. Therefore, DN is regarded as a "podocyte cell disease" $[3,4]$. We and others have found that high glucose stimuli can cause podocyte cells epithelial to mesenchymal cell transition (EMT) [5, 6].

Vitamin D receptor (VDR) belongs to the superfamily of nuclear hormone receptors, which encompasses receptors for steroid and thyroid hormones and retinoic acid [7]. It has been well documented that $1,25(\mathrm{OH})_{2} \mathrm{D}_{3}$ mediates the VDR's biological effects by binding to it and then recruiting cofactors to form a transcriptional complex that binds to vitamin D response elements (VDRE) in the promoter region of target genes to alter transcriptional events within the target cells $[8,9]$. Recent studies have shown that VDR-mediated signal transduction pathways play a critical role in the development of DN, such as inflammatory response [10], immune regulation, reduction of proteinuria, inhibition of the Ras system $[9,11]$, and prevention of fibrosis [12].VDR can prevent the progression of diabetes by promoting islet cell repair and reducing insulin resistance and glucose tolerance(13).

Paricalcitol (19-nor-1, 25-hydroxy-vitamin D2), a synthetic vitamin D analog, can reduce urinary albumin in type 2 DM patients $[9,13-15]$. As a vitamin D receptor agonist, it has been used for the treatment of hyperparathyroidism. Several studies have indicated that paricalcitol has renoprotective effects, including anti-inflammatory and anti-fibrotic effects in various nephropathy models (17). However, the mechanism of action for this drug has not been fully elucidated. The Wnt/ $\beta$-catenin pathway is now recognized as one of the most important signaling pathways involved in EMT[16] and GSK-3 $\beta$ plays an important role in the regulation of the $\beta$-catenin pathway [17].We have recently reported that VDR, GSK-3 $\beta$, $\beta$-catenin are co-localized in podocytes under high glucose conditions [18]. However, the relationships among VDR, GSK-3 $\beta$, and $\beta$-catenin remain unclear. The present study was designed to investigate the renoprotective effects of paricalcitol on mouse podocytes and reduction of proteinuria in DN mouse models and to explore the Wnt/GSK- $3 \beta / \beta$-catenin signaling pathway in its renoprotective mechanisms.

\section{Materials and Methods}

All the experimental procedures were performed in accordance with guidelines and regulations of the Ethics Committee of the First Affiliated Hospital of Zhengzhou University.

SiRNA

Based on the sequence of mouse full-length GSK-3 $\beta$ gene (GenBank NO. NM 019827.6), the siRNA against GSK-3ßwas designed as 5'-CCA CTC AAG AAC TGT CAA GTA-3') and the scramble siRNA control was 5'-UUC UCC GAA CGU GUC ACG UTT-3'. The GSK-3 $\beta$ and scramble siRNAs were transfected into the differentiated podocytes in the presence of Lipofectamine 2000 (Invitrogen, San Diego, CA, USA).

Cell culture and treatments

Undifferentiated mouse podocytes were provided by Prof. Peter Mundel (Mount Sinai Medical School, New York, NY, USA) and were cultured in RPMI1640 medium (GIBCO, Carlsbad, CA, USA) supplemented with $10 \%$ fetal bovine serum (FBS) (GIBCO), $5.6 \mathrm{mmol} / \mathrm{L}$ of glucose, and $10 \mathrm{U} / \mathrm{mL}$ of recombinant mice interferon- $\gamma$, in an incubator at $33^{\circ} \mathrm{C}$ with $5 \% \mathrm{CO}_{2}$. After differentiation, the podocytes were cultured at $37^{\circ} \mathrm{C}$ in RPMI1640 medium without interferon- $\gamma$. The podocytes were cultured for 12-14 days for the subsequent experiments. For the siRNA experiments, the podocytes were incubated in RPMI-1640 medium with normal 


\section{Cellular Physiology Cell Physiol Biochem 2017;43:39-51 \begin{tabular}{ll|l} 
DOI: 10.1159/000480315 24,2017 & $\begin{array}{l}\text { O 2017 The Author(s). Published by S. Karger AG, Basel } \\
\text { www.karger.com/cpb }\end{array}$ \\
\hline and Biochemistry
\end{tabular} Guo et al.: Proteinuria and High-Glucose-Induced Injury of Kidneys and Podocytes}

glucose and divided into three groups: (1) normal control group (NG, $5.6 \mathrm{mmol} / \mathrm{L}$ ); (2) scramble siRNA control group (scrsiRNA): treated with $100 \mathrm{pmol} / \mathrm{L}$ of scramble siRNA; and (3) VDRsiRNA group (vdrsiRNA): treated with100pmol/L of VDRsiRNA. For the study of the effects of paricalcitol, the podocytes were divided into six groups: (1) the normal control (5.6 mmol/L of glucose) group (NG); (2) the NG plus DMSO $(0.1 \mu \mathrm{mol} / \mathrm{L})$ group(NG+D); (3) the NG plus paricalcitol $(0.1 \mu \mathrm{mol} / \mathrm{L})$ group $(\mathrm{NG}+\mathrm{P})$; (4) the high glucose (25 mmol/L of glucose)group (25G); (5) the HG plus DMSO $(0.1 \mu \mathrm{mol} / \mathrm{L})$ group $(25 \mathrm{G}+\mathrm{D})$; and (6) the HG plus paricalcitol $(0.1 \mu \mathrm{mol} / \mathrm{L})$ group $(25 \mathrm{G}+\mathrm{P})$.For the study of the role of GSK-3 $\beta$, the podocytes were divided into six groups: (1) normal glucose (5.6 mmol/L of glucose) group (NG); (2) NG plus $100 \mathrm{pmol} / \mathrm{L}$ of scramble siRNA group (scramble); (3) NG plus $100 \mathrm{pmol} / \mathrm{L}$ of GSK$3 \beta$ siRNA group (GSKsiRNA); (4) NG plus Paricalcitol (0.1 $\mu \mathrm{mol} / \mathrm{L})$ group (PAR); (5)

Paricalcitol $(0.1 \mu \mathrm{mol} / \mathrm{L})$ plus $100 \mathrm{pmol} / \mathrm{L}$ of scramble siRNA group (PAR+scramble), and (6) Paricalcitol $(0.1 \mu \mathrm{mol} / \mathrm{L})$ plus $100 \mathrm{pmol} / \mathrm{L}$ of GSK-3 $\beta$ siRNA group (PAR+ GSKsiRNA).

\section{Real-time PCR}

Total RNA was extracted using Trizol reagent (Invitrogen Inc.), according to the manufacturer's instructions. The RNA purity was determined using absorbance at 260 and $280 \mathrm{~nm}(\mathrm{~A} 260 / 280)$ and the cDNA was synthesized using $2 \mu \mathrm{g}$ of RNA and the First StcDNA Synthesis Kit (Fermentas, Burlington, Canada) using the M-MuLV Reverse Transcriptase and random primers. The sequences of specific primers used in the present study are shown in Table 1. The cDNA $(1 \mu \mathrm{L})$ was mixed with the forward and reverse primers $(0.5 \mu \mathrm{L}$ each), $2 \times$ PCR MasterMix (12.5 $\mu$; Life Technologies Co., Grand Island, NY, USA) and deionized water (in total volume of $25 \mu \mathrm{L}$ ); the reaction was performed in a thermocycler (BD Diagnostics, Sparks, MD, USA) under the conditions of cycle shown in Table 2. After completion of the reaction to confirm the amplification curve and melting curve, the CT values of the corresponding index was calculated as $\Delta \Delta \mathrm{CT}$ by the following formula: $\Delta \Delta \mathrm{CT}$ : (CtA2-CtB2)-(CtA1-CtB1). Wherein A represents the target gene Ct values, $\mathrm{B}$ for reference gene $C t$ values, 1 and 2 represent different treatment groups. The experiment was repeated three times, and the average values were reported. The results calculated by the target gene treatment group with $2-\Delta \Delta \mathrm{CT}$ times higher than the target gene were expressed. The PCR products were separated by $2.0 \%$ agarose gel electrophoresis. The Image J image software (National Institutes of Health, Bethesda, MD, USA) was used to quantify the grayscale values.

\section{Western blotting analysis}

The total cellular proteins were obtained from each group using the RIPA lysis buffer (Dingguo Changsheng Biotech Co., Ltd., Beijing, China). Proteins were quantified using a BCA protein assay kit (Dingguo Changsheng Biotech Co., Ltd.). The samples with equal amount of total proteins $(20 \mu \mathrm{g})$ were separated using $10 \%$ SDS-PAGE and were transferred on PVDF membranes (Roche, Mannheim, Germany). The membranes were blocked using 5\% powdered milk diluted in TBS containing $0.05 \%$ Tween 20 (TBST) for $1 \mathrm{~h}$. The primary 


\section{Cellular Physiology Cell Physiol Biochem 2017;43:39-51 \begin{tabular}{l|l} 
DOI: 10.1159/000480315 & and Biochemistry \\
Published online: August 24, 2017 & $\begin{array}{l}\text { O 2017 The Author(s). Published by S. Karger AG, Basel } \\
\text { www.karger.com/cpb }\end{array}$
\end{tabular} \\ Guo et al.: Proteinuria and High-Glucose-Induced Injury of Kidneys and Podocytes}

antibody was incubated overnight at $4^{\circ} \mathrm{C}$. After washing with PBS, the secondary antibody was incubated at $37^{\circ} \mathrm{C}$ for 2h. An ECL chemiluminescence reagent kit (CoWin Biotech, Beijing, China) was used to view the protein bands. The blots were analyzed using the ImageJ software. The antibodies used

Table 3. The antibodies used in the present study

\begin{tabular}{|c|c|c|c|c|}
\hline Protein & Antibody & \multicolumn{2}{|l|}{ Vendor } & $\begin{array}{l}\text { Dilution } \\
\text { information }\end{array}$ \\
\hline GAPDH & $\begin{array}{c}\text { mouse anti } \\
\text { mouse }\end{array}$ & \multicolumn{2}{|c|}{$\begin{array}{c}\text { Shanghai Kang Cheng biological engineering Co., Ltd, } \\
\text { China }\end{array}$} & $1: 1000$ \\
\hline VDR & $\begin{array}{l}\text { mouse anti } \\
\text { mouse }\end{array}$ & \multicolumn{2}{|c|}{ Santa Cruz Biotechnology, Santa Cruz, CA, USA } & $1: 1000$ \\
\hline $\begin{array}{l}\beta- \\
\text { catenin }\end{array}$ & $\begin{array}{l}\text { mouse anti } \\
\text { mouse }\end{array}$ & \multicolumn{2}{|c|}{ Abcam, Cambridge,UK } & $1: 1000$ \\
\hline GSK-3 $\beta$ & $\begin{array}{l}\text { mouse anti } \\
\text { mouse }\end{array}$ & Abcam, Cambridge,UK & $1 a b 3239$ & $1: 2000$ \\
\hline$\alpha$-SMA & $\begin{array}{l}\text { mouse anti } \\
\text { mouse }\end{array}$ & Abcam, Cambridge,UK & , ab7817 & $1: 2000$ \\
\hline nephrin, & $\begin{array}{l}\text { rabbit anti } \\
\text { mouse }\end{array}$ & Abcam, Cambridge,UK & , ab58968, & $1: 1000$ \\
\hline podocin, & $\begin{array}{l}\text { rabbit anti } \\
\text { mouse }\end{array}$ & Abcam, Cambridge,UK & , ab50993, & $1: 1000$ \\
\hline MMP9 & $\begin{array}{l}\text { rabbit anti } \\
\text { mouse }\end{array}$ & \multicolumn{2}{|c|}{ Abcam, Cambridge,UK } & $1: 1000$ \\
\hline
\end{tabular}

in the present study are shown in Table 3. And the secondary antibody horseradish phorseradish peroxidase-labeled goat anti-rabbit IgG (1:2000) was obtained from Dingguo Changsheng Biotech Co., Ltd. (Beijing, China).

\section{Animals and treatments}

All the animal experimental procedures were reviewed and approved by the Ethics Committee of the First Affiliated Hospital of Zhengzhou University. The C57BL/KsJ db/db, six-week, male mice and agematched $\mathrm{db} / \mathrm{m}$ mice were purchased from Nanjing Center for Experimental Animals (Nanjing, China). The mice were housed at $25^{\circ} \mathrm{C}$ and $50-60 \%$ relative humidity, in a $12 \mathrm{~h} / 12 \mathrm{~h}$ light/dark cycle, with free access to food and water. The mice were randomly assigned to four groups (20 mice per group): 1$) \mathrm{db} / \mathrm{m}$ normal control group (group C, untreated), 2) db/db normal control group (group $\mathrm{N}$, untreated), 3) db/db vehicletreated group (group D, $0.3 \mu \mathrm{g} / \mathrm{kg}$, by intraperitoneal injection, i. P.), and 4) $\mathrm{db} / \mathrm{db}$ paricalcitol-treated group (group P, equal amounts of dimethylsulfoxide, i.p.). The treatments began at the age of 10 weeks and ended at 22 weeks old; all the treatments were performed three times a week (Days 1, 3, and 5 each week). Some of these mice were sacrificed at Weeks 10,14,18, and 22, respectively. All the mice were killed under $10 \%$ chloral hydrate anesthesia and the kidneys were then isolated.

\section{Measurements of renal function, blood glucose, and serum lipids}

For 24-h complete urine collection, the mice were placed individually in metabolic cages with free access to food and water. Urine albumin and creatinine were measured by the Kidney Lab of First Affiliated Hospital of Zhengzhou University. The blood samples were collected from the tail veins after fasting for $8 \mathrm{~h}$ (during experiments), and by cardiac puncture (at the end of experiments). Serum levels of glucose (GLU), creatinine, urea nitrogen, uric acid, triglyceride (TG), cholesterol (TC), glycated serum protein (GSP) and albumin/creatinine ratios were all assayed using an Automatic Biochemistry Analyzer CS-400 (Changchun Dirui Medical Technology Co Ltd, Changchun, China).

\section{Histology and immunofluorescence}

The removed kidneys were weighed and the cortices were then separated. The left cortices were snapfrozen for Western blotting and real-time PCR analyses, and the right cortices were used for pathological analyses. The renal tissues were fixed in Bouin's solution, embedded in paraffin, cut into 5 - $\mu \mathrm{m}$ sections, and stained with periodic acid-Schiff (PAS) and H\&E staining. For immunofluorescence analysis, the renal cortex of $1 \mathrm{~mm} \times 1 \mathrm{~mm} \times 1 \mathrm{~mm}$ was fixed in $2.5 \%$ glutaraldehyde and the remaining kidney tissues were fixed in $4 \%$ paraformaldehyde.

The podocytes were stimulated by $25 \mathrm{mmol} /$ Lof glucose for $36 \mathrm{~h}$, and fixed in $4^{\circ} \mathrm{C} 4 \%$ paraformaldehyde for $20 \mathrm{~min}$ and $0.6 \%$ Tween-20 for $15 \mathrm{~min}$, and then blocked with 5\% BSA blocking solution for $20 \mathrm{~min}$ at room temperature. The cells were exposed to antibodies against VDR, Nephrin, Podocin, $\alpha$-SMA, and MMP9 overnight. The cells were washed three times with PBS, and then incubated with the Alexa Fluor 488 goat anti-rabbit IgG $(\mathrm{H}+\mathrm{L})$ (green) and the Alexa Fluor 594 donkey anti-mouse IgG $(\mathrm{H}+\mathrm{L})$ (red) (Invitrogen Inc., Carlsbad, CA, USA) at $37^{\circ} \mathrm{C}$ for $1 \mathrm{~h}$. The fluorescence was observed under a fluorescence microscope (Olympus, CX31-32RFL, Japan). 


\section{Cellular Physiology Cell Physiol Biochem 2017;43:39-51 \begin{tabular}{c|c|c|c|} 
DOI: 10.1159/000480315 & C 2017 The Author(s). Published by S. Karger AG, Basel \\
wwww.karger.com/cpb
\end{tabular} \\ Guo et al.: Proteinuria and High-Glucose-Induced Injury of Kidneys and Podocytes}

Statistical analysis

The data are expressed as means \pm SD. SPSS 17.0 software (Chicago, IL, USA) was used for the statistical analysis. Two-way analysis of variance (ANOVA) was used for the multi-group comparisons, and Least Significant Difference (LSD) Test was performed for pair-wise comparison. $P<0.05$ was considered statistically significant.

\section{Results}

Effects of VDR expression level on gene expression and barrier function of podocytes

In order to determine the relationship between the VDR expression and phenotype and barrier function of podocytes, we used a siRNA to knock down the expression of VDR. As shown in Fig. 1, Western blotting analyses demonstrated that, compared with control groups, VDR siRNA resulted in the down-regulation of the protein levels of VDR, nephrin, and podocin $(P<0.05)$ and the up-regulation of the protein levels of $\alpha$-SMA and MMP9 $(P<0.05)$.The results of qRT-PCR analyses indicated that (Fig. 2), the mRNA expression levels of VDR, nephrin, and podocin were all down-regulated, compared with the control groups $(P<0.05)$ and the mRNA expression levels of $\alpha$-SMA and MMP9 were up-regulated $(P<0.05)$. The results of the albumin flow indicated that VDR siRNA treatment resulted in an increase in the albumin flow of the podocytes $(P<0.05)$.

\section{Effects of paricalcitol on gene expression of the Wht signaling pathway}

Our previous experimental results have found that, under high glucose conditions, the expression of GSK-3 $\beta$ and $\beta$-catenin is increased, indicating that the activity of Wnt signaling pathway is increased. In the present study, Western blotting analyses indicated that, compared with the NG group, the expressions of $\alpha$-SMA, MMP9,GSK-3 $\beta$, and $\beta$-catenin

Fig. 1. Western blotting analysis for protein expression after VDR siRNA knock out.*: compared with NG group and scrsiRNA group, p<0.05 for VDR; \#: compared with NG group and scrsiRNA group, $\mathrm{p}<0.05$ for GSK-3 $\beta$;\&: compared with NG group and scrsiRNA group, $\mathrm{p}<0.05$ for $\beta$-catenin; $\alpha$ : compared with NG group and scrsiRNA group, $\mathrm{p}<0.05$ for podcin; $\beta$ : compared with NG group and scrsiRNA group, $\mathrm{p}<0.05$ for nephrin; $\gamma$ : compared with NG group and scrsiRNA group, $\mathrm{p}<0.05$ for $\alpha-S M A ; \delta$ : compared with NG group and scrsiRNA group, $\mathrm{p}<0.05$ for MMP9.

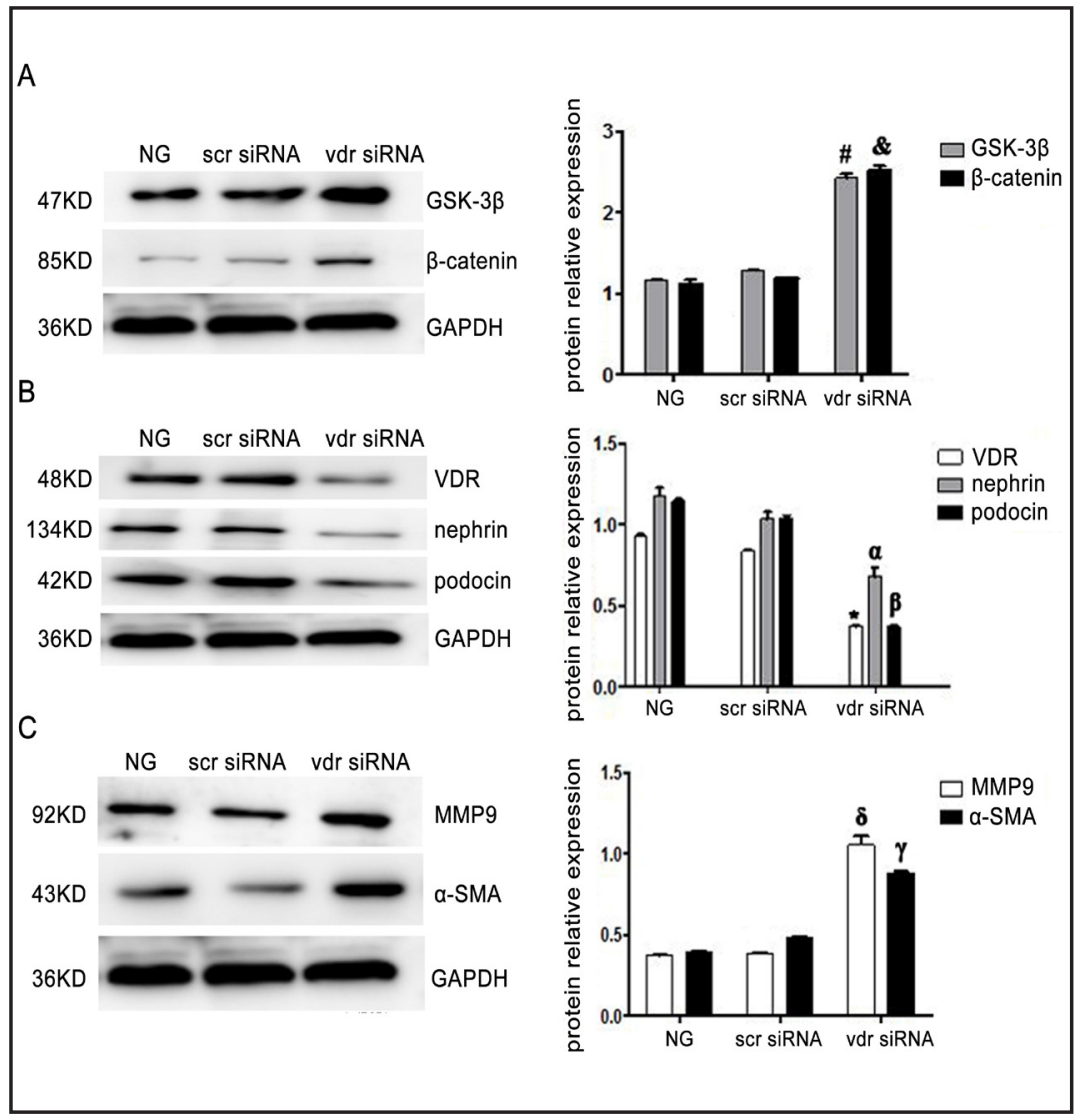




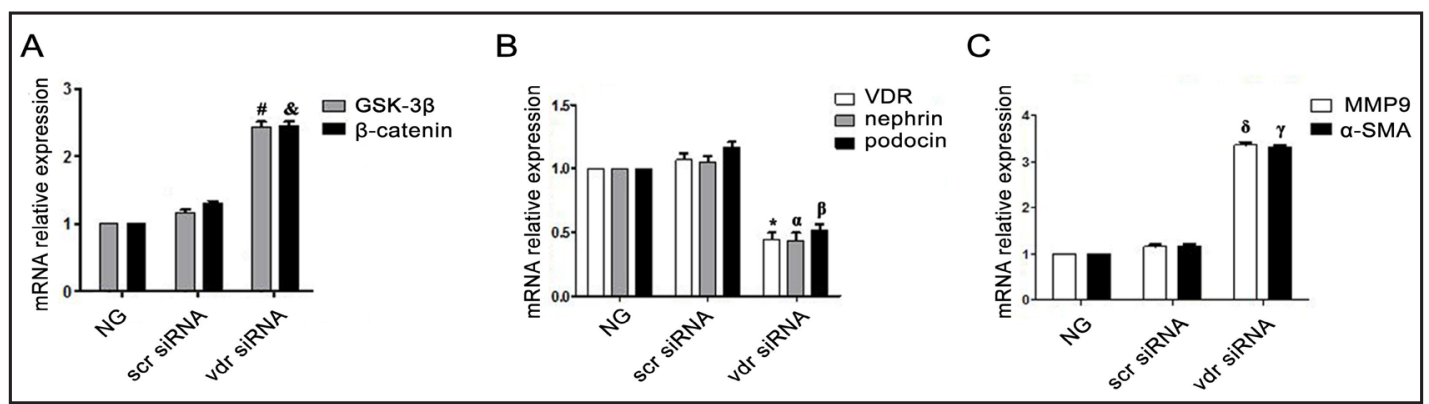

Fig. 2. qRT-PCR analysis for gene expression after VDR siRNA knock out.*: compared with NG group and

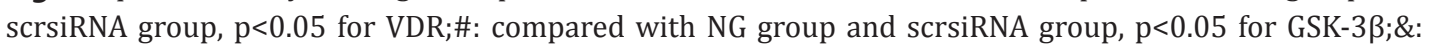
compared with NG group and scrsiRNA group, $\mathrm{p}<0.05$ for $\beta$-catenin; $\alpha$ : compared with NG group and scrsiRNA group, $p<0.05$ for podcin; $\beta$ : compared with NG group and scrsiRNA group, $p<0.05$ for nephrin; $\gamma$ : compared with NG group and scrsiRNA group, $\mathrm{p}<0.05$ for $\alpha-S M A ; \delta$ : compared with NG group and scrsiRNA group, $\mathrm{p}<0.05$ for MMP9.

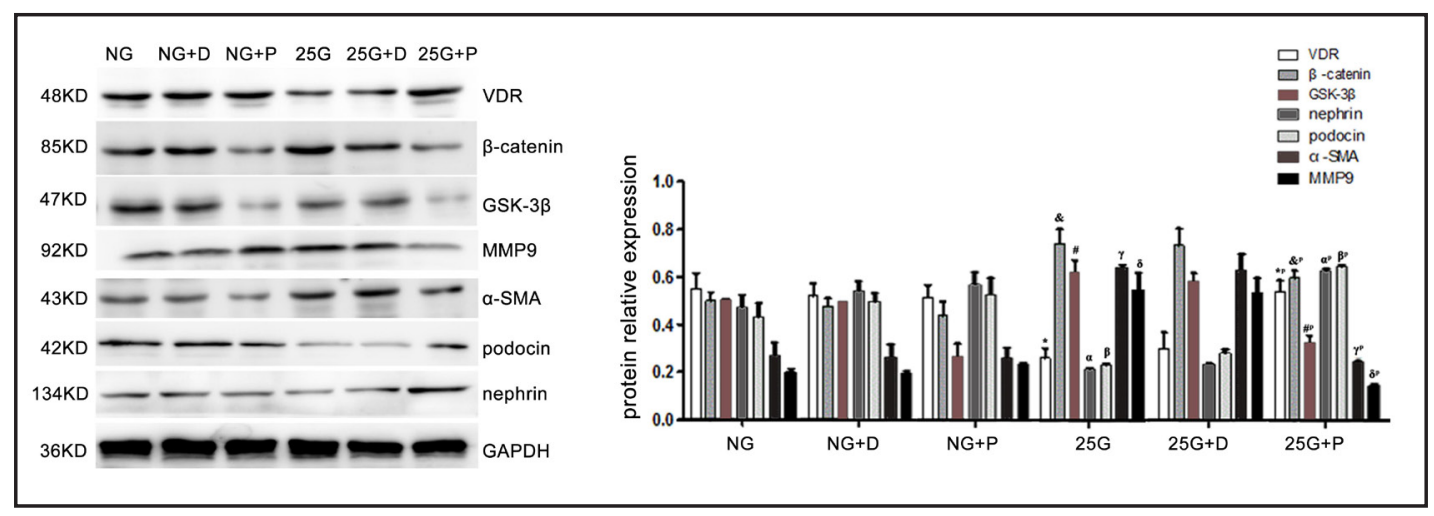

Fig. 3. Western blotting analysis for the effects of paricalcitol on protein expression.*: compared with NG group, $\mathrm{p}<0.05$ for VDR;\#: compared with NG group, $\mathrm{p}<0.05$ for GSK-3 $\beta$;\&: compared with NG group, $\mathrm{p}<0.05$ for $\beta$-catenin; $\alpha$ : compared with NG group, $\mathrm{p}<0.05$ for podcin; $\beta$ : compared with NG group, $\mathrm{p}<0.05$ for nephrin; $\gamma$ : compared with NG group, $\mathrm{p}<0.05$ for $\alpha-S M A ; \delta$ : compared with NG group, $\mathrm{p}<0.05$ for MMP9.*p: compared with 25G group, $\mathrm{p}<0.05$ for VDR; $\mathrm{p}$ : compared with 25G group, $\mathrm{p}<0.05$ for GSK-3ß;\&p: compared with $25 \mathrm{G}$ group, $\mathrm{p}<0.05$ for $\beta$-catenin; $\alpha \mathrm{p}$ : compared with $25 \mathrm{G}$ group, $\mathrm{p}<0.05$ for podcin; $\beta \mathrm{p}$ : compared with $25 \mathrm{G}$ group, $\mathrm{p}<0.05$ for nephrin; $\gamma \mathrm{p}$ : compared with $25 \mathrm{G}$ group, $\mathrm{p}<0.05$ for $\alpha-S M A ; \delta \mathrm{p}$ : compared with $25 \mathrm{G}$ group, $\mathrm{p}<0.05$ for MMP9.

were up-regulated and the levels of VDR, nephrin, and podocin were decreased in the high glucose group, which was reversed by paricalcitol (Fig. 3).The qRT-PCR results indicated that, compared with the NG group, the mRNA expressions of $\alpha$-SMA, MMP9,GSK-3 $\beta$ and $\beta$-catenin were up-regulated and the expression levels of VDR, nephrin, and podocin were decreased in the high glucose group, which was reversed by paricalcitol treatment (Fig. 4).

\section{Effects of GSK-3 $\beta$ siRNA on gene expressions of the Wnt signaling pathway}

We next determined the influence of VDR on $\beta$-catenin under the condition of siRNA knockdown ofGSK-3 $\beta$. The results of Western blotting analyses indicated that, compared with control groups,GSK-3 $\beta$ siRNA resulted in the up-regulation of VDR, nephrin, and podocin $(P<0.05)$ and the down-regulation of $\alpha$-SMA,MMP9,GSK-3 $\beta$, and $\beta$-catenin $(P<0.05$, Fig. 5), which was not affected by paricalcitol treatment. The qRT-PCR analyses indicated that, compared with control groups, GSK-3 $\beta$ siRNA treatment resulted in the increased mRNA expression of VDR, nephrin, and podocin and the decreased mRNAlevels of $\alpha$-SMA,MMP9,GSK$3 \beta$, and $\beta$-catenin $(P<0.05)$, which was not affected by paricalcitol treatment (Fig. 6). 


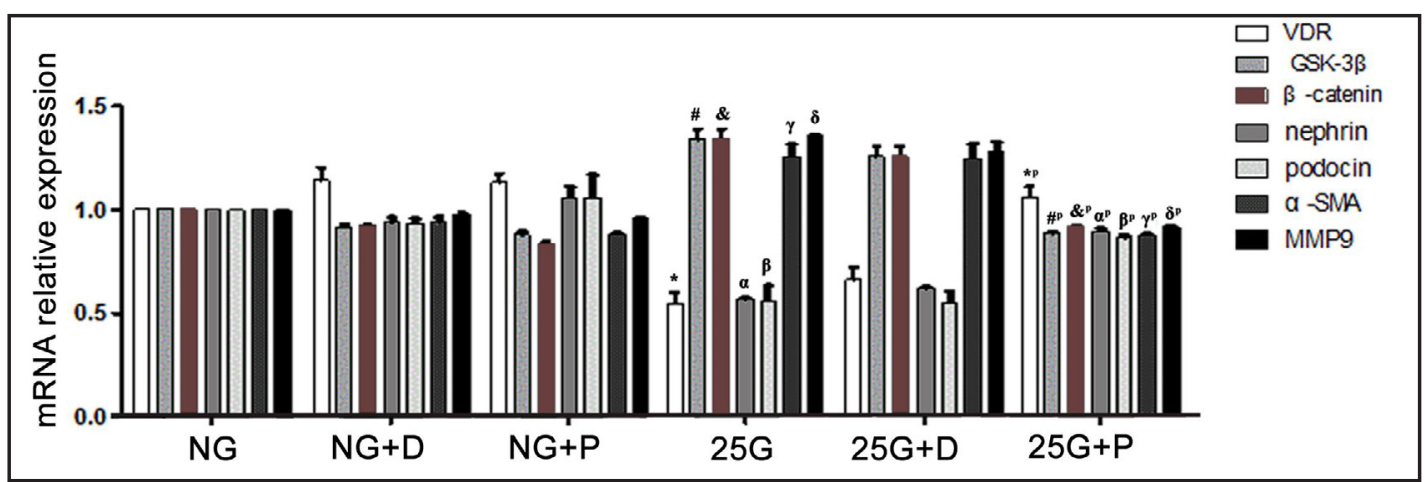

Fig. 4. qRT-PCR analysis for the effects of paricalcitol on gene expressions.*: compared with NG group, $\mathrm{p}<0.05$ for VDR; \#: compared with NG group, $\mathrm{p}<0.05$ for GSK-3 $\beta$;\&: compared with NG group, $\mathrm{p}<0.05$ for $\beta$-catenin; $\alpha$ : compared with NG group, $\mathrm{p}<0.05$ for podcin; $\beta$ : compared with NG group, $\mathrm{p}<0.05$ for nephrin; $\gamma$ : compared with NG group, $\mathrm{p}<0.05$ for $\alpha$-SMA; $\delta$ : compared with NG group, $\mathrm{p}<0.05$ for MMP9.*p: compared

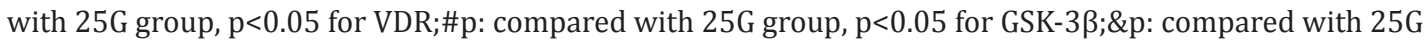
group, $\mathrm{p}<0.05$ for $\beta$-catenin; $\alpha$ : compared with $25 \mathrm{G}$ group, $\mathrm{p}<0.05$ for podcin; $\beta \mathrm{p}$ : compared with $25 \mathrm{G}$ group, $\mathrm{p}<0.05$ for nephrin; $\gamma \mathrm{p}$ : compared with $25 \mathrm{G}$ group, $\mathrm{p}<0.05$ for $\alpha-S M A ; \delta \mathrm{p}$ : compared with $25 \mathrm{G}$ group, $\mathrm{p}<0.05$ for MMP9.

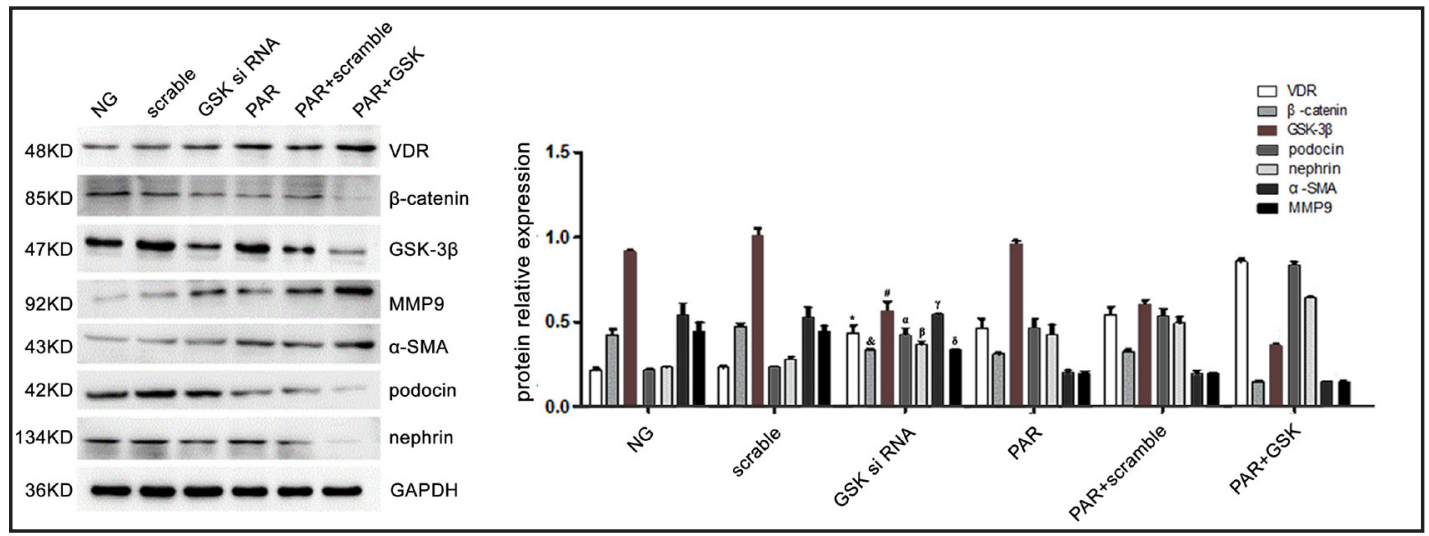

Fig. 5. Western blotting analysis for the role of GSK-3 $\beta$ in protein expression.*: compared with NG group,

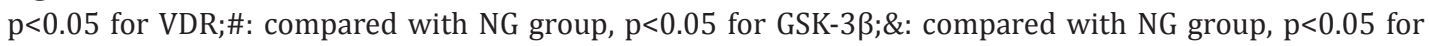
$\beta$-catenin; $\alpha$ : compared with NG group, $p<0.05$ for podcin; $\beta$ : compared with NG group, $p<0.05$ for nephrin; $\gamma$ : compared with NG group, $\mathrm{p}<0.05$ for $\alpha$-SMA; $\delta$ : compared with NG group, $\mathrm{p}<0.05$ for MMP9.

\section{Effects of paricalcitol on proteinuria and kidney injury in DN mice}

We next investigated whether paricalcitol was effective in ameliorating proteinuria in mice. The body weight, absolute body fat, food intake, water intake, and urine volume of $\mathrm{db}$ / $\mathrm{db}$ mice were consistently increased with age, compared with the normal control mice (Table 4). The 6-week old db/db diabetic mice also exhibited significantly higher blood glucose levels, which was consistently increased throughout the study period, compared with the normal control animals (Table 5). Early renoprotection effects of parcalcitol were examined by measuring the 24-h urinary albumin excretion (UAE) in the $\mathrm{db} / \mathrm{db}$ mice, compared with the controls. We treated the $\mathrm{db} / \mathrm{db}$ mice with paricalcitol starting at 10 weeks old and demonstrated that paricalcitol significantly ameliorated urinary albumin excretion in $\mathrm{db} / \mathrm{db}$ mice after only four weeks of treatment (Table 6). The 24-h urine protein levels of Scr and BUN were increased significantly in group $\mathrm{D}$ and group $\mathrm{N}$ compared with group $\mathrm{C}$, while decreased in group P compared with groups D and $\mathrm{N}$ (Table 6). This reduction of urinary albumin was maintained throughout the duration of the study. Collectively, the above observations revealed that an early stage of DN occurred at 6-week old. In comparison with groups D and $\mathrm{N}$, the treatment did not affect serum levels of triglycerides, cholesterol, glucose, and glycated

\section{KARGER}




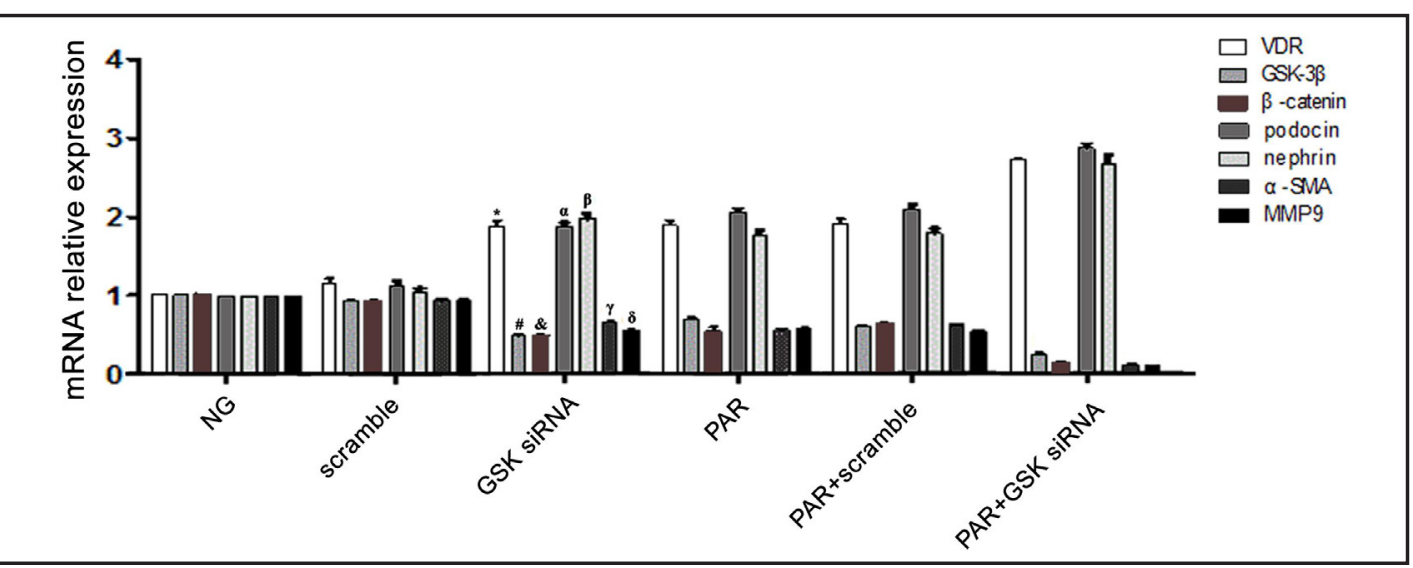

Fig. 6. qRT-PCR analysis for the role of GSK- $3 \beta$ in gene expression.*: compared with NG group, $p<0.05$ for VDR;\#: compared with NG group, $\mathrm{p}<0.05$ for GSK-3 $\beta$;\&: compared with NG group, $\mathrm{p}<0.05$ for $\beta$-catenin; $\alpha$ : compared with NG group, $\mathrm{p}<0.05$ for podcin; $\beta$ : compared with NG group, $\mathrm{p}<0.05$ for nephrin; $\gamma$ : compared with NG group, $\mathrm{p}<0.05$ for $\alpha$-SMA; $\delta$ : compared with NG group, $\mathrm{p}<0.05$ for MMP9.

serum proteins in group $P$. Additionally, paricalcitol did not affect body weight gain.

We further examined the effects of paricalcitol on the expression of VDR inrenal tissues of the $\mathrm{db} / \mathrm{db}$ mice and found that with the increase of week-age of $\mathrm{db} / \mathrm{db}$ mice, the expression of VDR was gradually decreased, which was reversed by paricalcitol (Figures 7 and 8). With the increase of week-age of $\mathrm{db} / \mathrm{db}$ mice, the expression of GSK-3 $\beta$ and its downstream molecule $\beta$-catenin, the key molecules in Wnt signaling pathway, were gradually increased, which was reversed by paricalcitol (Fig. 9). In kidney tissues of the $\mathrm{db} / \mathrm{db}$ mice, with the increase of week-age, the expressions of nephrin and podocin, the marker proteins of podocyte, were gradually decreased, and the expressions of $\alpha$-SMA and MMP9, the marker proteins of mesenchymal, were gradually increased, which were reversed by paricalcitol(Figures 10 and 11). Under the electron microscope, glomerular basement membrane in the renal tissues of $\mathrm{db} / \mathrm{db}$ mice and $\mathrm{db} /$ $\mathrm{db}-\mathrm{D}$ mice showed irregular thickening, had not deposited electron dense but with visible
Table 4. Comparison of body weights (g) from different groups at different time points, * compare with Group C at same week time, P $<0.05$ $(n=5)$

\begin{tabular}{lccccc}
\hline & 6 week & 10 week & 14 week & 18 week & 22 week \\
\hline Group C & $20.0 \pm 1.86$ & $21.58 \pm 1.42$ & $23.03 \pm 2.05$ & $24.3 \pm 1.34$ & $25.8 \pm 2.05$ \\
Group N & $34.36 \pm 2.23^{*}$ & $46.11 \pm 2.15^{*}$ & $54.6 \pm 2.32^{*}$ & $59.6 \pm 1.78^{*}$ & $60.4 \pm 2.31^{*}$ \\
Group D & $34.67 \pm 2.11^{*}$ & $47.21 \pm 2.45^{*}$ & $55.67 \pm 3.21^{*}$ & $60.4 \pm 2.45^{*}$ & $61.50 \pm 2.75^{*}$ \\
Group P & $35.01 \pm 1.78^{*}$ & $46.21 \pm 2.40^{*}$ & $55.07 \pm 1.68^{*}$ & $58.5 \pm 2.31^{*}$ & $60.7 \pm 1.87^{*}$ \\
\hline
\end{tabular}

Table 5. Comparison of blood glucose levels (mmol/L) among different groups at different time points, *compare with Group $\mathrm{C}$ at same week time, $\mathrm{P}<0.05(\mathrm{n}=5)$

\begin{tabular}{lccccc}
\hline & 6 week & 10 week & 14 week & 18 week & 22 week \\
\hline Group C & $7.96 \pm 1.56$ & $8.17 \pm 1.92$ & $8.24 \pm 1.87$ & $8.89 \pm 1.23$ & $8.88 \pm 1.56$ \\
Group N & $15.62 \pm 2.10^{*}$ & $18.34 \pm 1.50^{*}$ & $18.22 \pm 1.70^{*}$ & $25.60 \pm 2.23^{*}$ & $22.67 \pm 2.56^{*}$ \\
Group D & $16.66 \pm 2.01^{*}$ & $18.79 \pm 1.8^{*}$ & $18.48 \pm 1.2^{*}$ & $24.30 \pm 3.4^{*}$ & $26.8 \pm 3.8^{*}$ \\
Group P & $16.22 \pm 1.5^{*}$ & $18.34 \pm 1.1^{*}$ & $18.05 \pm 1.7^{*}$ & $24.7 \pm 2.6^{*}$ & $26.3 \pm 2.9^{*}$ \\
\hline
\end{tabular}

Table 6. Comparison of 24-h urinary albumin excretion (mg/L) among different groups at different time points, *: compare with Group $\mathrm{C}$ at same week time, $\mathrm{P}<0.05 ; \Delta$ : compare with Group $\mathrm{N}$ at same week time, $\mathrm{P}$ $<0.05$; \# :compare with Group D at same week time, $\mathrm{P}<0.05(\mathrm{n}=5)$

\begin{tabular}{lccccc}
\hline & 6 week & 10 week & 14 week & 18 week & 22 week \\
\hline Group C & $1.21 \pm 0.57$ & $2.23 \pm 0.68$ & $2.01 \pm 0.21$ & $2.56 \pm 0.78$ & $2.07 \pm 0.45$ \\
Group N & $5.3 \pm 2.71^{*}$ & $12.64 \pm 2.2^{*}$ & $14.32 \pm 1.44^{*}$ & $16.56 \pm 3.34^{*}$ & $18.9 \pm 2.67^{*}$ \\
Group D & $5.41 \pm 2.21^{*}$ & $13.43 \pm 3.11^{*}$ & $13.89 \pm 2.67^{*}$ & $17.23 \pm 2.45^{*}$ & $18.32 \pm 3.12^{*}$ \\
Group P & $6.1 \pm 2.34^{*}$ & $12.9 \pm 1.08^{*}$ & $11.8 \pm 1.77^{* \Delta^{*}}$ & $9.34 \pm 1.22^{*} \Delta^{\#}$ & $8.67 \pm 1.56^{*}$ \\
\hline
\end{tabular}




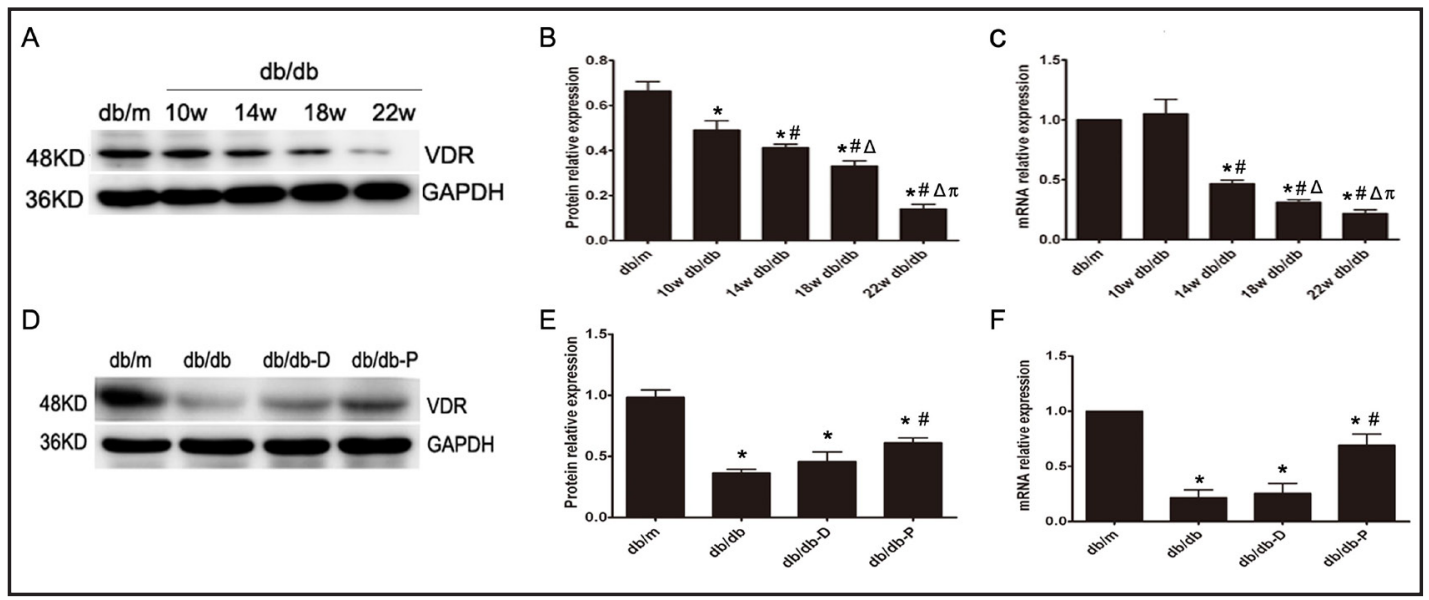

Fig. 7. Western blotting analysis of the expression of VDR in kidney tissues from mice with different ages and different treatments. A, B: different week-old mice kidney tissue VDR Western Blotting results and analysis; C: Different Diets mouse kidney organization VDR qRT-PCR analysis; D, E: 22 weeks of different treated mice kidney tissue VDR Western Blotting results and analysis, F: 22 weeks of different treated mice kidney tissue VDR qRT-PCR analysis. (Note: B, C in *: Compared with $\mathrm{db} / \mathrm{m} \mathrm{P}<0.05$; \#: and 10w db/db compared $\mathrm{P}<0.05 ; \Delta$ : with $14 \mathrm{w} \mathrm{db} / \mathrm{db}$ compared $\mathrm{P}<0.05 ; \pi$ : and $18 \mathrm{w} \mathrm{db} / \mathrm{db}$ compared to $\mathrm{P}<0.05 . \mathrm{E}, \mathrm{F} *$ in: the $\mathrm{db} / \mathrm{m}$ compared to $\mathrm{P}<0.05$; \#: $\mathrm{P}$ compared with $\mathrm{db} / \mathrm{db}$ group and $\mathrm{db} / \mathrm{db}-\mathrm{D}$ group $<0.05$ ).

foot process fusion; paricalcitol treatment improved the morphology: glomerular basement membrane was homogeneous smooth without thickening and foot process fusion was no visible. Paricalcitol alleviated the foot process fusion of the podocytes in the db/db mice (Fig. 12).

We also examined whether this protection was associated with renal function in the $\mathrm{db} /$ $\mathrm{db}$ mice. A decline in glomerular filtration rate (GFR) was observed in mice of 17-weeks or older; as a result, an elevation in serum creatinine (SCR) was frequently reported at 16 weeks or older (Table 7). Paricalcitol significantly reduced the SCR levels in the $d b / d b$ mice, indicating an improvement in the renal function.

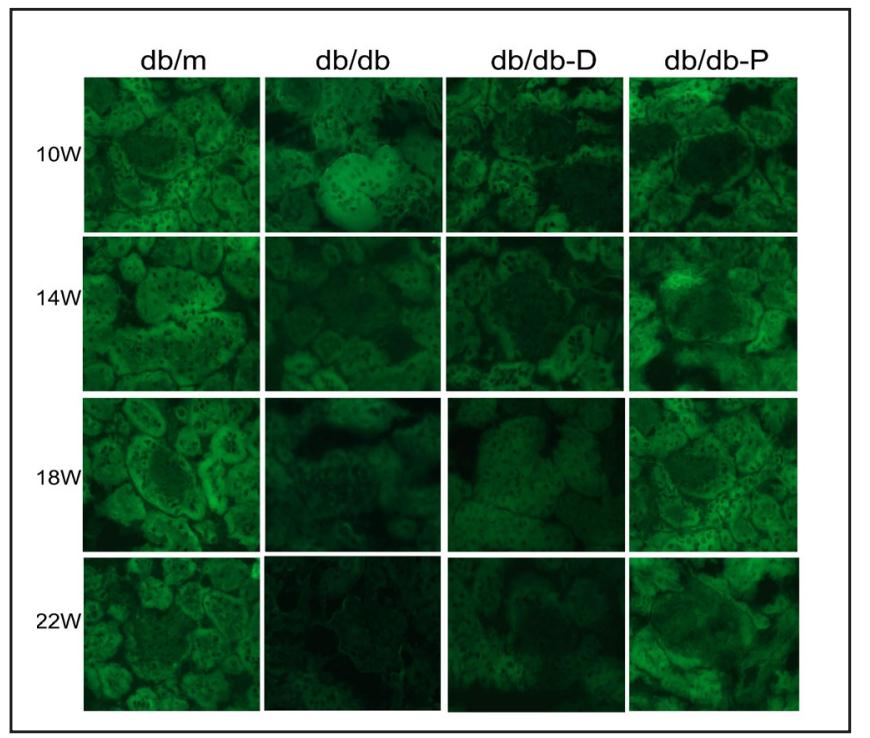

Fig. 8. Immunofluorescence analysis for the expression of VDR in kidney tissues from mice at different ages and with different treatment.

\section{Discussion}

Vitamin D and VDR could provide possible renoprotection against DN[12]. More fibronectin and less nephrin are expressed in the VDR knockout mice compared to diabetic wild-type mice. In the present study, down-regulation of VDR by siRNA decreased the expression of nephrin and podocin and increased the expression of $\alpha$-SMA and MMP9. 


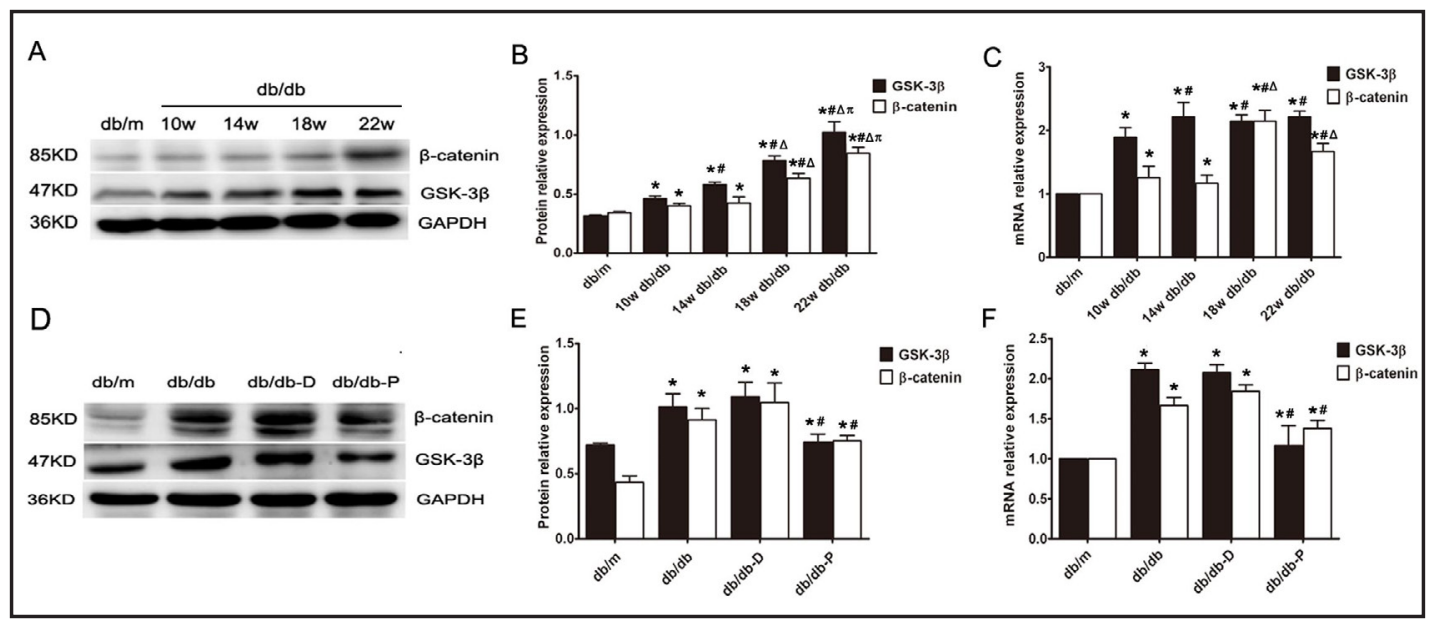

Fig. 9. Comparison of the expression of GSK-3 $\beta$ and $\beta$-catenin in kidney tissues of the mice at different ages and with different treatments. A, B: Western Blot results of GSK- $3 \beta$ and $\beta$-catenin of $\mathrm{db} / \mathrm{db}$ mice in different ages; C.: qRT-PCR results of GSK-3 $\beta$ and $\beta$-catenin of $\mathrm{db} / \mathrm{db}$ mice in different ages; $\mathrm{D}, \mathrm{E}$ : Western Blot results of GSK-3 $\beta$ and $\beta$-catenin of mice in different treatment groups on the 22-week; F: qRT-PCR results of GSK-3 3 and $\beta$-catenin of mice in different treatment groups on the 22-week (Note: in B and C: *: compared with db / $\mathrm{m} \mathrm{P}<0.05$; \#: and $10 \mathrm{w} \mathrm{db} / \mathrm{db}$ phase ratio $\mathrm{P}<0.05 ; \Delta$ : with $14 \mathrm{w} \mathrm{db} / \mathrm{db}$ compared to $\mathrm{P}<0.05 ; \pi$ : and $18 \mathrm{w} \mathrm{db} /$ db compared to $\mathrm{P}<0.05$. in $\mathrm{E}$ and $\mathrm{F}:{ }^{*}$ : the $\mathrm{db} / \mathrm{m}$ compared to $\mathrm{P}<0.05$; \#: and $\mathrm{db} / \mathrm{db}$ group and db/db-D group compared to $\mathrm{P}<0.05$.).

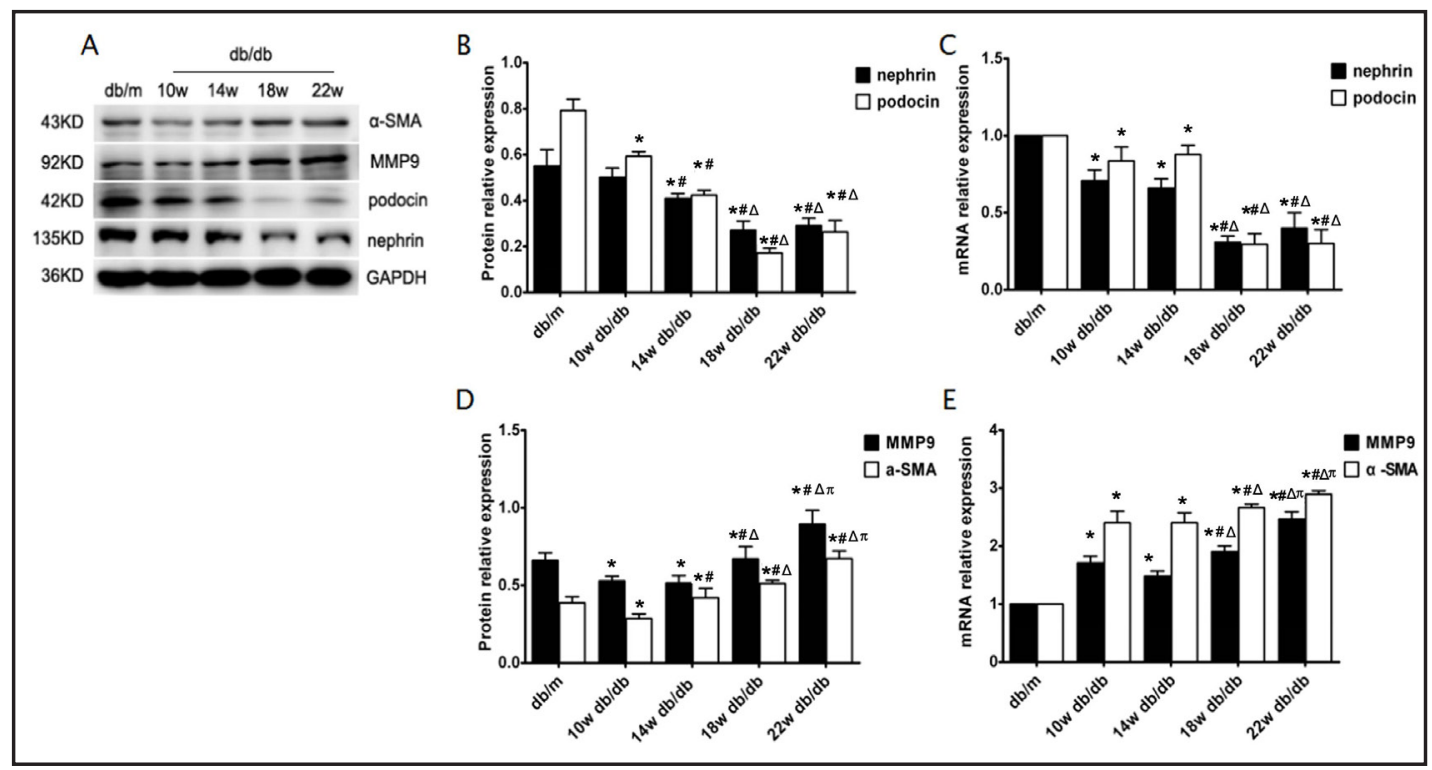

Fig. 10. Comparison of expressions of nephrin, podocin, $\alpha$-SMA, and MMP9 of db/db mice at different ages. A: Western Blot results of nephrinpodocin, $\alpha$-SMA and MMP9of db/db mice indifferent ages; B: Western Blot results of nephrin andpodocin; C: qRT- PCR results of nephrin and podocin; D: Western Blot results of $\alpha$-SMA and MMP9; E: qRT- PCR results of $\alpha$-SMA and MMP9. (Note: *: and db / m compared to P <0.05; \#: and 10w $\mathrm{db} / \mathrm{db}$ compared to $\mathrm{P}<0.05 ; \Delta$ : Compared with $14 \mathrm{w} \mathrm{db} / \mathrm{db} \mathrm{P}<0.05 ; \pi$ : Compared with $18 \mathrm{w} \mathrm{db} / \mathrm{db} \mathrm{P}<0.05$.).

The Wnt signaling pathway plays an important role in the regulation of differentiation of cellar morphology and function and $\beta$-catenin is a multifunctional protein and is a key factor involved in classic Wnt signaling. Under normal physiological conditions, the Wnt signaling pathway in kidney is "static", axin, APC, and GSK-3 $\beta$ combine with $\beta$-catenin, making $\beta$-catenin phosphorylated [19-21].In our previous experiment, the expressions of GSK-3 $\beta$ 


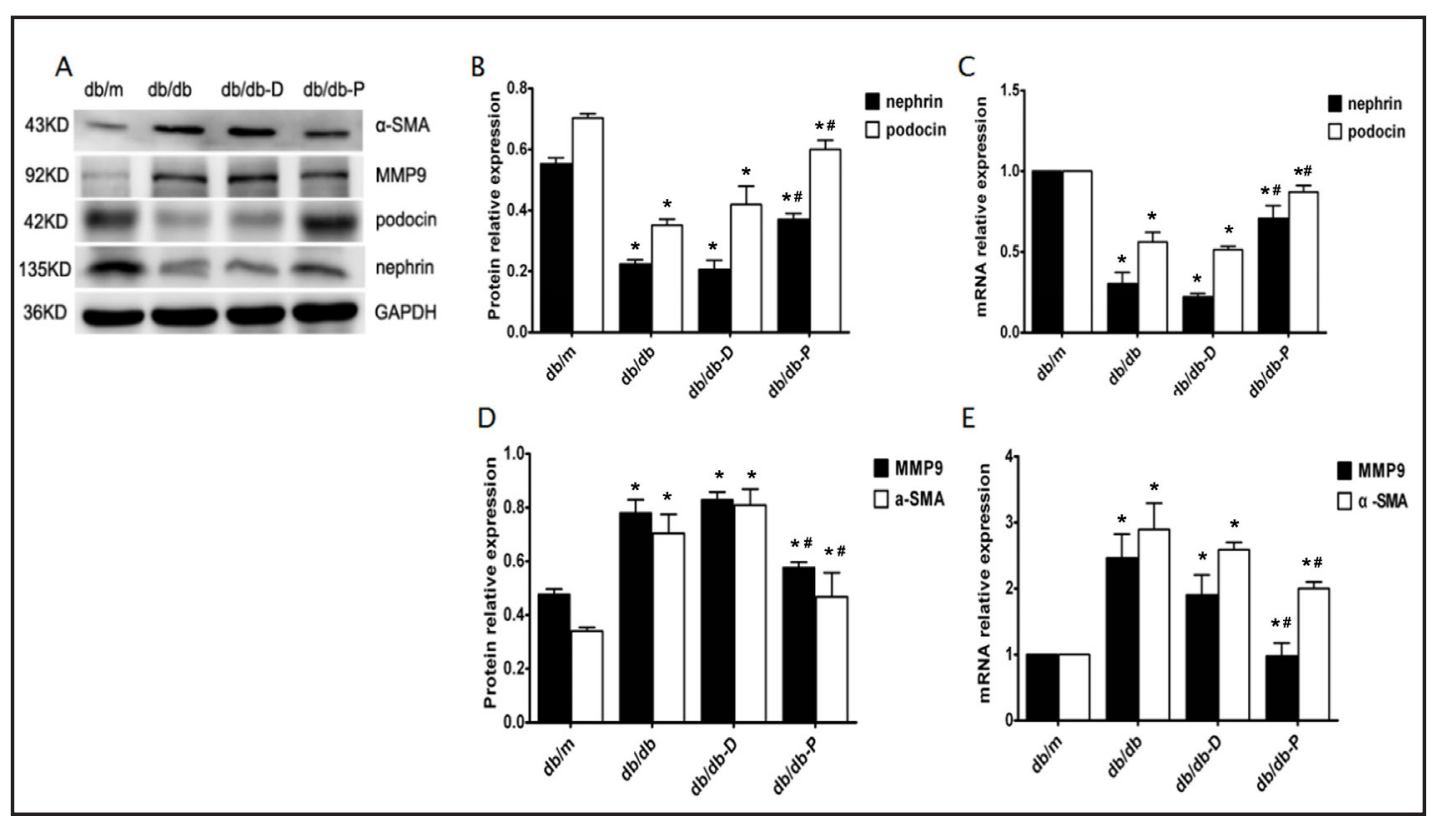

Fig. 11. Comparison of expression of nephrin, podocin, $\alpha$-SMA and MMP9 of mice with different treatments. A: Western Blot results of nephrinpodocin, $\alpha$-SMA and MMP9of mice indifferent treatment groups; B: Western Blot results of nephrin and podocin; C: qRT- PCR results of nephrin and podocin; D: Western Blot results of $\alpha$-SMA and MMP9; E: qRT- PCR results of $\alpha$-SMA and MMP9. (Note: *: compared with db / $\mathrm{m} \mathrm{P<0.05;} \mathrm{\# :} \mathrm{P}$ compared with $\mathrm{db} / \mathrm{db}$ group and $\mathrm{db} / \mathrm{db}-\mathrm{D}$ Group $<0.05$ ).

Fig. 12. TEM analysis of the renal tissues of $\mathrm{db} / \mathrm{db}$ mice and $\mathrm{db} / \mathrm{db}-\mathrm{D}$ mice. Glomerular basement membrane showed irregular thicken, had not deposited electron dense and the foot process fusion was visible; compared with $\mathrm{db} /$ $\mathrm{db}$ mice, the lesions of renal tissue in $\mathrm{db} /$ $\mathrm{db}$ - P mouse was improved. Glomerular basement membrane in renal tissue of $\mathrm{db} / \mathrm{m}$ mice was homogeneous smooth without thickening, and foot process fusion was no visible.

and $\beta$-catenin were increased under the high glucose condition, and consequently the expression of mesenchymal marker proteins were increased, and barrier function of podocytes was destroyed. And the expression of VDR and $\beta$-catenin were co-localized in the nuclei. The expression of VDR was decreased after using GSK-3 $\beta$ inhibitor to interfere the expression of GSK$3 \beta$ in the renal tissues of $d b / d b$

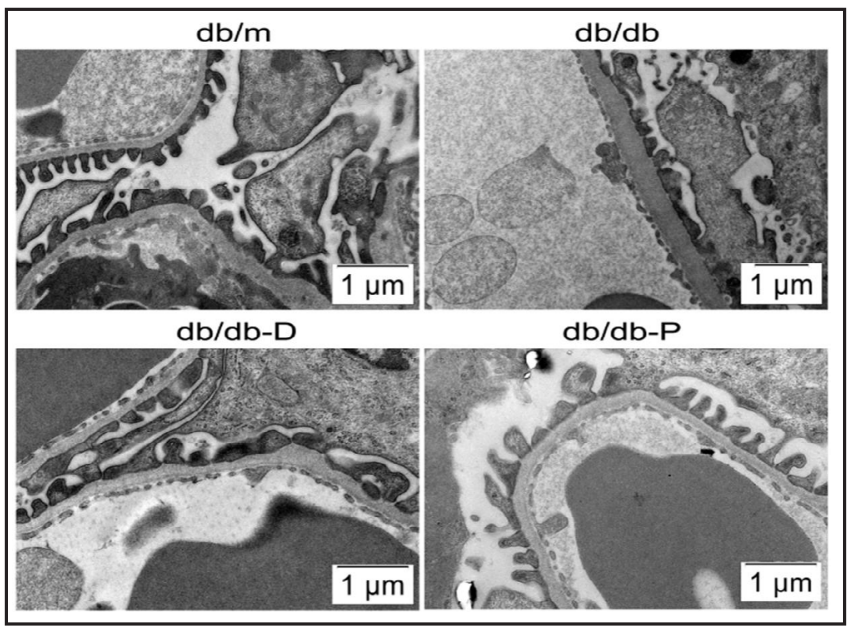

Table 7. Comparison of serum creatinine ( $\mu \mathrm{mol} / \mathrm{L})$ among different groups at different time points, *: compare with Group $\mathrm{C}$ at same week time, $\mathrm{P}<0.05 ; \Delta$ : compare with Group $\mathrm{N}$ at same week time, $\mathrm{P}<0.05$; \# : compare with Group D at same week time, $\mathrm{P}<0.05(\mathrm{n}=5)$

\begin{tabular}{cccccc}
\hline & 6 week & 10 week & 14 week & 18 week & 22 week \\
\hline Group C & $26.71 \pm 3.14$ & $26.88 \pm 2.87$ & $28.32 \pm 2.22$ & $28.12 \pm 2.34$ & $28.69 \pm 3.45$ \\
Group N & $27.12 \pm 3.03$ & $40.77 \pm 2.12^{*}$ & $48.77 \pm 3.56^{*}$ & $51.89 \pm 2.79^{*}$ & $55.67 \pm 3.27^{*}$ \\
Group D & $27.32 \pm 2.73$ & $40.11 \pm 3.21^{*}$ & $48.44 \pm 4.32^{*}$ & $52.49 \pm 3.89^{*}$ & $56.05 \pm 2.33^{*}$ \\
Group P & $27.45 \pm 1.67$ & $41.56 \pm 4.15^{*}$ & $42.7 \pm 3.67^{* \Delta^{\#}}$ & $37.67 \pm 4.15^{* \Delta^{\sharp}}$ & $35.4 \pm 4.05^{*} \Delta^{*}$ \\
\hline
\end{tabular}




\section{Cellular Physiology Cell Physiol Biochem 2017;43:39-51 \begin{tabular}{l|l} 
DOI: 10.1159/000480315 & and Biochemistry \\
Published online: August 24, 2017 & $\begin{array}{l}\text { O 2017 The Author(s). Published by S. Karger AG, Basel } \\
\text { www.karger.com/cpb }\end{array}$ \\
\hline
\end{tabular}

mice, but the interaction of VDR with GSK-3 $\beta$ and $\beta$-catenin remains unclear. The present study showed that with down-regulation of GSK-3$\beta$ expression, the expression of $\beta$-catenin was decreased and the expression of VDR increased.

In the present study, the $\mathrm{db} / \mathrm{db}$ mice at six weeks of age exhibited hyperglycemia and albuminuria. With increasing age, the disease progressed and kidney function deteriorated further, resulting in a significant rise in albuminuria and renal fibrosis. Though there were some studies about the roles of some potential chemicals or drugs on diabetic kidney injury, our study showed the new role and mechanism of VDR agonist [22, 23]. The results from the present study demonstrated that paricalcitol possessed an impressive renal protective efficacy in DN. Considering the pathologic sequences of this model, it is conceivable that the reno-protective effect of paricalcitol may be primarily attributable to its prevention of podocyte injury. This notion was further substantiated by the observations that paricalcitol prevented the loss of podocyte-specific nephrin, podocin. Interestingly, this anti-proteinuric action of this vitamin $\mathrm{D}$ analogs has also been reported in several clinical studies in patients with chronic renal insufficiency, as well as in other animal models of proteinuric kidney diseases [24]. Therefore, it is becoming clear that paricalcitol is quite effective in alleviating podocyte injury and proteinuria under different circumstances [25, 26].

Hyperglycemia leads to nephropathy by various mechanisms, such as increased end othelial cell permeability to albumin, hypertrophy, thickening of the basement membrane and renal fibrosis $[27,28]$. In the present study, our data demonstrated that the expressions of GSK-3 $\beta, \beta$-catenin, $\alpha$-SMA, and MMP9 were increased under high glucose condition, and these changes were attenuated by paricalcitol pretreatment. Additionally, paricalcitol could reverse the decrease in the levels of VDR, nephrin, and podocin caused by high glucose, further confirming its effects on prevention of renal injury in DN. These results may provide a basis for further rationale use of this drug in the clinic to treat and prevent DN.

\section{Acknowledgements}

This work was financially supported by the National Natural Science Foundation of China (Grant Nos. 81400726, 81670663 and 81570690), the National Key Research and Development Program (No. 2016YFC1305404) and the key program of Joint Funds of the National Natural Science Foundation of China (No. U1604284).

\section{Disclosure Statement}

The authors have declared none conflict of interests.

\section{References}

1 Checherita IA, Manda G, Hinescu ME, Peride I, Niculae A, Bilha S, Gramaticu A, Voroneanu L, Covic A: New molecular insights in diabetic nephropathy. Int Urol Nephrol 2016;48:373-387.

2 Montero RM, Covic A, Gnudi L, Goldsmith D: Diabetic nephropathy: What does the future hold? Int Urol Nephrol 2016;48:99-113.

-3 Liu J, Li QX, Wang XJ, Zhang C, Duan YQ, Wang ZY, Zhang Y, Yu X, Li NJ, Sun JP, Yi F: beta-Arrestins promote podocyte injury by inhibition of autophagy in diabetic nephropathy. Cell Death Dis 2016;7:e2183.

4 Cao AL, Wang L, Chen X, Wang YM, Guo HJ, Chu S, Liu C, Zhang XM, Peng W: Ursodeoxycholic acid and 4-phenylbutyrate prevent endoplasmic reticulum stress-induced podocyte apoptosis in diabetic nephropathy. Lab Invest 2016;96:610-622.

5 Liu H, Wang X, Liu S, Li H, Yuan X, Feng B, Bai H, Zhao B, Chu Y: Effects and mechanism of miR-23b on glucose-mediated epithelial-to-mesenchymal transition in diabetic nephropathy. Int J Biochem Cell Biol 2016;70:149-160. 


\section{Cellular Physiology Cell Physiol Biochem 2017;43:39-51 \begin{tabular}{ll|l} 
DOI: 10.1159/000480315 24,2017 & $\begin{array}{l}\text { O 2017 The Author(s). Published by S. Karger AG, Basel } \\
\text { www.karger.com/cpb }\end{array}$
\end{tabular}

6 Loeffler I, Wolf G: Epithelial-to-Mesenchymal Transition in Diabetic Nephropathy: Fact or Fiction? Cells 2015;4:631-652.

7 Wang Y, Deb DK, Zhang Z, Sun T, Liu W, Yoon D, Kong J, Chen Y, Chang A, Li YC: Vitamin D receptor signaling in podocytes protects against diabetic nephropathy. J Am Soc Nephrol 2012;23:1977-1986.

-8 Derakhshanian H, Shab-Bidar S, Speakman JR, Nadimi H, Djafarian K: Vitamin D and diabetic nephropathy: A systematic review and meta-analysis. Nutrition 2015;31:1189-1194.

-9 Chokhandre MK, Mahmoud MI, Hakami T, Jafer M, Inamdar AS: Vitamin D \& its analogues in type 2 diabetic nephropathy: a systematic review. J Diabetes Metab Disord 2015;14:58.

10 Kanasaki K, Taduri G, Koya D: Diabetic nephropathy: the role of inflammation in fibroblast activation and kidney fibrosis. Front Endocrinol (Lausanne) 2013;4:7.

11 Tian Y, Lv G, Yang Y, Zhang Y, Yu R, Zhu J, Xiao L: Effects of vitamin D on renal fibrosis in diabetic nephropathy model rats. Int J Clin Exp Pathol 2014;7:3028-3037.

-12 Sanchez-Nino MD, Bozic M, Cordoba-Lanus E, Valcheva P, Gracia O, Ibarz M, Fernandez E, Navarro-Gonzalez JF, Ortiz A, Valdivielso JM: Beyond proteinuria: VDR activation reduces renal inflammation in experimental diabetic nephropathy. Am J Physiol Renal Physiol 2012;302:F647-657.

13 Joergensen C, Tarnow L, Goetze JP, Rossing P: Vitamin D analogue therapy, cardiovascular risk and kidney function in people with Type 1 diabetes mellitus and diabetic nephropathy: a randomized trial. Diabet Med 2015;32:374-381.

14 Fernandez-Fernandez B, Ortiz A, Gomez-Guerrero C, Egido J: Therapeutic approaches to diabetic nephropathy--beyond the RAS. Nat Rev Nephrol 2014;10:325-346.

15 Ireland R: Diabetic nephropathy: Paricalcitol lowers residual albuminuria in type 2 diabetes. Nat Rev Nephrol 2011;7:62.

16 Xiao L, Wang M, Yang S, Liu F, Sun L: A glimpse of the pathogenetic mechanisms of Wnt/beta-catenin signaling in diabetic nephropathy. Biomed Res Int 2013;2013:987064.

17 Lee YJ, Han HJ: Troglitazone ameliorates high glucose-induced EMT and dysfunction of SGLTs through PI3K/Akt, GSK-3beta, Snail1, and beta-catenin in renal proximal tubule cells. Am J Physiol Renal Physiol 2010;298:F1263-1275.

18 Guo J, Xia N, Yang L, Zhou S, Zhang Q, Qiao Y, Liu Z: GSK-3beta and vitamin D receptor are involved in betacatenin and snail signaling in high glucose-induced epithelial-mesenchymal transition of mouse podocytes. Cell Physiol Biochem 2014;33:1087-1096.

19 Zhou L, Liu Y: Wnt/beta-catenin signalling and podocyte dysfunction in proteinuric kidney disease. Nat Rev Nephrol 2015;11:535-545.

20 Li C, Siragy HM: High glucose induces podocyte injury via enhanced (pro)renin receptor-Wnt-beta-cateninsnail signaling pathway. PLoS One 2014;9:e89233.

-21 Dai C, Stolz DB, Kiss LP, Monga SP, Holzman LB, Liu Y: Wnt/beta-catenin signaling promotes podocyte dysfunction and albuminuria. J Am Soc Nephrol 2009;20:1997-2008.

-22 Li Q Li J, Shao H, Li X-X, Yu F, Xu M: Inhibition of CPU0213, a Dual Endothelin Receptor Antagonist, on Apoptosis via Nox4-Dependent ROS in HK-2 Cells. Cell Physiol Biochem 2016;39:183-192.

23 Li X, Wang L, Gao X, Li G, Cao H, Song D, Cai S, Liang T, Zhang B, Du G: Mechanisms of protective effect of ramulus mori polysaccharides on renal injury in high-fat diet/streptozotocin-induced diabetic rats. Cell Physiol Biochem 2015;37:2125-2134.

24 Mann MC, Hobbs AJ, Hemmelgarn BR, Roberts DJ, Ahmed SB, Rabi DM: Effect of oral vitamin D analogs on mortality and cardiovascular outcomes among adults with chronic kidney disease: a meta-analysis. Clin Kidney J 2015;8:41-48.

25 Ekart R, Bevc S, Hojs R, Hojs N: Proteinuria and Albuminuria During and After Paricalcitol Treatment in Chronic Kidney Disease Patients. J Clin Pharmacol 2016;56:761-768.

26 Hojs N, Bevc S, Balon BP, Hojs R, Ekart R: Paricalcitol reduces proteinuria in non-dialysis chronic kidney disease patients. Ther Apher Dial 2013;17:368-372.

27 Wang D, Guan M-P, Zheng Z-J, Li W-Q Lyv F-P, Pang R-Y, Xue Y-M: Transcription factor Egr1 is involved in high glucose-induced proliferation and fibrosis in rat glomerular mesangial cells. Cell Physiol Biochem 2015;36:2093-2107.

28 Luo X, Deng L, Lamsal LP, Xu W, Xiang C, Cheng L: AMP-activated protein kinase alleviates extracellular matrix accumulation in high glucose-induced renal fibroblasts through mTOR signaling pathway. Cell Physiol Biochem 2015;35:191-200. 